\title{
Peertechz
}

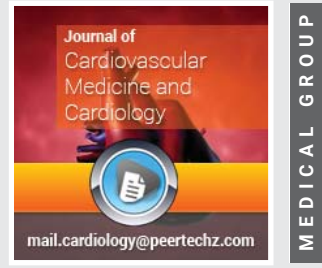

\section{Relation of hs-CRP and Glycogen phosphorylase BB in Acute Myocardial Infarction Patients}

\author{
Neelima singh ${ }^{1}$, Chanchal Garg ${ }^{2 *}$, Puneet Rastogi ${ }^{3}$, Rakesh \\ Shah $^{4}$, Vedika Rathore ${ }^{5}$, Roshan Kumar Mahat ${ }^{6}$ and Prerna \\ Vyas Gokhle ${ }^{7}$
}

${ }^{1}$ Professor and Vice- Chancellor of Kota University, Kota, India

${ }^{2} \mathrm{PhD}$ Scholar, G.R. Medical College, Gwalior, India

${ }^{3}$ Professor and HOD of Cardiology, G.R. Medical College, Gwalior, India

${ }^{4} \mathrm{PhD}$ Scholar, G.R. Medical College, Gwalior, India

${ }^{5}$ Assistant Professor, S.S. Medical College, Rewa, India

${ }^{6}$ Assistant Professor, Govt. medical college, Baripada, India

${ }^{7} \mathrm{PhD}$ Scholar, G.R. Medical College, Gwalior, India

Received: 05 August, 2020

Accepted: 29 August, 2020

Published: 31 August, 2020

*Corresponding author: Chanchal Garg, PhD Scholar, Biochemistry, G.R.Medical College, Gwalior, Madhya Pradesh, India, Tel: 7415407035;

E-mail: gargchanchal108@gmail.com

Keywords: Acute myocardial infarction; Inflammation; Glycogen phosphorylase BB; Hs-CRP

https://www.peertechz.com

Check for updates

\section{Abstract \\ Background: Inflammation has important role in the pathophysiology of atherosclerosis and acute myocardial infraction and hs-CRP is an inflammatory marker. GPBB is a marker of myocardial necrosis or myocardial ischemia i.e. the initial phase of AMI. The aim of this study was to know the levels of GPB and the relation between hs-} CRP and GPBB in AMI patients.

Materials \& methods: This study was conducted in the Cardiology of J.A. Hospital and Department of biochemistry, G.R. Medical College, Gwalior. Patients were admitted with severe chest pain out of which 100 were included in this study. 50 normal healthy individuals were also selected. Blood samples were collected at the admission time for the analysis of hs-CRP and GPBB. All patients underwent thorough clinical examination and investigations. Estimation of GPBB and hs-CRP were done by ELISA method and other routine parameters done by enzymatic method.

Results: The mean level of GPBB in patients was $46.92 \mathrm{ng} / \mathrm{mL}$ while in controls it was $13.88 \mathrm{ng} / \mathrm{mL}$. The mean level of hs-CRP in patients was $4.38 \mathrm{mg} / \mathrm{L}$ while in controls it was $1.34 \mathrm{mg} / \mathrm{L}$. There was highly significant difference of GPBB and hs-CRP in control group and AMI group. The finding of results showed that hs-CRP and GPBB was positively correlated. The levels of FBG, Triglyceride, Cholesterol, LDL, and VLDL were significantly increased and HDL was decreased in AMI group when compare controls.

Conclusion: Our results demonstrate that there was positive correlation of hs-CRP and GPBB in AMI patients. So along with GPBB, hs-CRP is also additional marker of myocardial ischemia and AMI.

\section{Introduction}

Acute Myocardial Infraction (AMI) is a severe condition in which inadequate supply of blood and oxygen to a portion of the myocardium tissue. It typically occurs an imbalance between myocardial oxygen supply and demand. The most common cause of this is atherosclerosis. It is because a regional reduction myocardial blood flow and inadequate perfusion of the myocardium supplied [1]. The fourth universal definition of MI is based on elevated high sensitivity cardiac troponin 
(hs-cTn). The criteria for the detection of MI increased hscTn with at least one of these: symptoms of acute myocardial ischemia, new ECG changes or development of pathological $Q$ waves [2]. But, the clinical applications of cTn still have certain limitations because the rise of hs-cTn occurs after 4 hours following the onset of myocardial injury, this may not deserve in early diagnosis of MI within first 1-2 hours. With the development of hs-cTn analysis, diagnostic sensitivity has been further improved; however, specificity is relatively reduced [3]. Myoglobin is an early and sensitive marker it starts to rise in the blood 2 hour after following onset of myocardial necrosis but the specificity for the diagnosis MI to some extent [4]. Other marker CK-MB that is specific and starts to elevate within 3-4 hour after onset of myocardial injury but sensitivity is not higher [5,6]. C-reactive protein (CRP) is a plasma protein that participates in the acute systemic response to inflammation and its plasma concentration increases during inflammatory states and hs-CRP is a sensitive indicator of inflammation which is closely related to plaque formation and is an independent prognostic marker in patients with ACS $[7,8]$. Several studies have also reported that hs-CRP was a diagnostic biomarker for AMI and could potentially reflect the extent of myocardial injury in STEMI $[4,9]$. So we need to a better marker for early detection that sensitivity and specificity should be high and decline these limitations. It also seemed that a single biomarker could not possibly provide sufficient sensitivity and specificity in diagnosis and prognosis of MI. A multi biomarker approach may enhance the early diagnostic value and provide more information for the early risk stratification of MI. Here, we reported a biomarker, i.e. Glycogen Phosphorylase BB or GPBB, which may possibly play important roles in MI.

GPBB is an isoenzyme of glycogen phosphorylase. It is highly expressed in heart and brain tissues and is responsible for energy production during muscle contraction. It has an essential role in the process of glycogenolysis. During myocardial ischemia, GPBB accelerates glycogenolysis for anaerobic glycolysis. It can be detached from glycogen and released into the plasma when cell membrane permeability increases following myocardial ischemic insult. GPBB is very sensitive as its plasma concentration usually increases within 1-4 h after AMI, making it comparable to Myoglobin in terms of sensitivity. Previously, large amounts of evidence showed that GPBB could be a promising biomarker for myocardial infarction [10-12]. However, few studies have focused on the diagnostic performance of circulating GPBB levels in patients of MI. In this study we investigated the diagnostic value of GPBB and correlate it with hs-CRP in detection of AMI.

\section{Materials and methods}

The study population was constituted by two groups: Control group and AMI group. In healthy control group were 50 clinically healthy subjects for routine physical examination in outpatient department. In AMI group a total of 100 cases that had sudden chest pain and admitted in CCU, Department of Cardiology, JAH hospital, Gwalior. This is the case control study in which all subjects in these two groups were matched for age and gender, respectively. After admission, clinical data were collected and documented for all patients, including sex, age, presence of hypertension, diabetes, drinker, smoker etc. Venous blood samples were obtained at admission for AMI group and in the next morning after at least $8 \mathrm{~h}$ of fasting condition. For control group fasting blood sample were taken. Biochemical tests to determine the levels of total cholesterol (TC), triglycerides (TG), high density lipoprotein (HDL), low density lipoprotein (LDL), creatine kinase $\mathrm{MB}(\mathrm{CK}-\mathrm{MB})$, glycogen phosphorylase BB (GPBB) and high-sensitivity C-reactive protein (hs-CRP) were performed. Fasting blood glucose (FBG) was determined using hexokinase method, and hemoglobin A1c (HbA1c) level was assessed by high-performance liquid chromatography method. The plasma lipid and lipoprotein, including TC, TG, HDL-C, LDL-C, were detected by enzymatic method. The concentration of the GPBB and hs-CRP were measured using an enzyme-linked immune-sorbent assay (ELISA) kit method. Standard 12-lead ECGs finding was also collected. All patients recruited in the current study provided written informed consent. This study was approved by the Ethical Committee of G.R. Medical College.

\section{Statistical analysis}

The data were analyzed by the software program Statistical Package for Social Sciences (SPSS version 20, Chicago). Descriptive characteristics and the lipid profile of the study patients were calculated as mean \pm SD values. KolmogorovSmirnov and Shapiro-Wilk tests were used to see that data is following normal distribution. Student's t-test was used to assess differences in age, BP, BMI, RBG, HbA1c, TG, TC, HDL, LDL, hs-CRP and GPBB. Relationship of hs-CRP levels with cardiac enzyme i.e. GPBB was determined by Spearman's correlation analysis. Linear regression analysis was also performed to see the predictive relationship between hs-CRP with GPBB in AMI patients. The difference was considered statistically significant at $\mathrm{P}<0.05$.

\section{Results}

150 subjects were included in the present study. Of these, 100 were in AMI group and rests 100 were healthy group. The baseline characteristics showed in Table I. The demographic characteristics such as age, sex were not significantly different among the two groups. The mean level of hs-CRP was significantly higher in AMI group $(\mathrm{p}<0.001)$ as well as GPBB level was also found to be higher and statistically significant when compare with control group. The table II shows Spearman's correlation analysis in which hs-CRP levels correlated significantly with GPBB. So, linear regression analysis was performed to see the relationship between hsCRP and GPBB in AMI group. There was a significant predictive positive relation of hs-CRP with GPBB.

\section{Discussion}

There were many different studies that showed the role and diagnostic value of hs-CRP and GPBB in separate but in very few studies it show together. In the current study we investigate the diagnostic value to GPBB and find out 
the correlation of GPBB with hs-CRP in AMI patients. In our finding we get the highly increase level of GPBB in AMI group when we compare it with control group $(44.36 \pm 18.54)$. It is statistically significant $(<0.001)$ GPBB is very sensitive as its plasma concentration usually increases within $1-4 \mathrm{~h}$ after AMI. In the recent Singh et al (2018) study this cardiac marker and concluded that GPBB is the highly sensitive marker and it can be used as additional biomarker for the early diagnosis of AMI [13]. Cubranic, et al. [14], Bozkurt, et al. [15] and Serdar et al found in their study that GPBB was the most efficient marker when compare with other cardiac markers in early diagnostic of AMI [16]. Lillpopp et al in 2012 measured the GPBB levels in patients of AMI and found that GPBB is valuable in improving the mid-term prognosis in these patients [17]. GPBB is very sensitive as its plasma concentration usually increases within 1-4 h after myocardial ischemia; In 2005 Peetz, et al. studied

Table 1: Shows comparison of baseline characteristic between control and AMI group.

\begin{tabular}{|c|c|c|c|}
\hline Parameters & Control group $(\mathbf{n = 5 0})$ & AMI group $(\mathbf{n = 1 0 0})$ & $\boldsymbol{p}$-value \\
\hline Age & $52.62 \pm 7.76$ & $56.15 \pm 8.19$ & $>0.001$ \\
\hline BMI & $22.30 \pm 2.31$ & $23.04 \pm 1.81$ & $>0.001$ \\
\hline SBP & $116.90 \pm 8.32$ & $139.5 \pm 11.76 \star \star$ & $<0.001$ \\
\hline DBP & $79.40 \pm 7.26$ & $94.35 \pm 11.99 \star \star$ & $<0.001$ \\
\hline FBG & $90.56 \pm 14.21$ & $164.58 \pm 58^{\star \star}$ & $<0.001$ \\
\hline HbA1c & $4.72 \pm 0.40$ & $7.41 \pm 1.48^{\star \star}$ & $<0.001$ \\
\hline TG & $109.56 \pm 19.32$ & $214.52 \pm 27.32^{\star \star}$ & $<0.001$ \\
\hline TC & $146.90 \pm 10.78$ & $219.51 \pm 22.51 \star \star$ & $<0.001$ \\
\hline HDL & $47.43 \pm 7.41$ & $34.77 \pm 4.89 \star \star$ & $<0.001$ \\
\hline LDL & $81.88 \pm 13.76$ & $141.54 \pm 21.30 \star$ & $<0.001$ \\
\hline hs-CRP & $1.34 \pm 0.36$ & $4.38 \pm 0.85^{\star \star}$ & $<0.001$ \\
\hline GPBB & $13.88 \pm 3.76$ & $46.92 \pm 18.43^{\star \star}$ & $<0.001$ \\
\hline
\end{tabular}

Table II: Shows Spearman's correlation between hs-CRP and GPBB in AMI group.

\begin{tabular}{|c|c|c|}
\hline Parameter & hs-CRP & GPBB \\
\hline hs-CRP & 1.000 & $0.7545^{\star \star}$ \\
\hline GPBB & $0.7545^{\star \star}$ & 1.000 \\
\hline
\end{tabular}

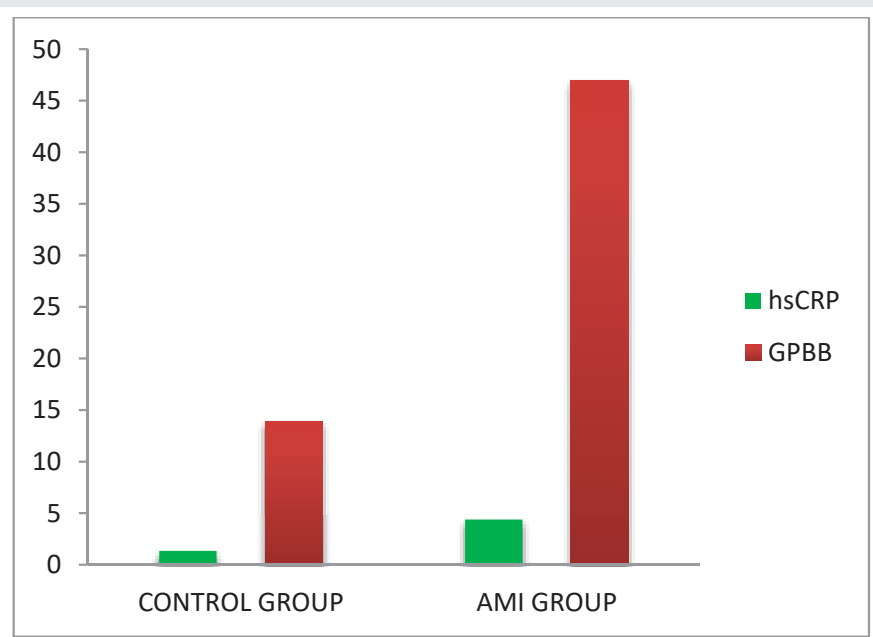

Graph 1: Showing the mean levels of hs-CRP and GPBB in control and AMI group

\section{CORRELATION OF hs-CRP AND GPBB}

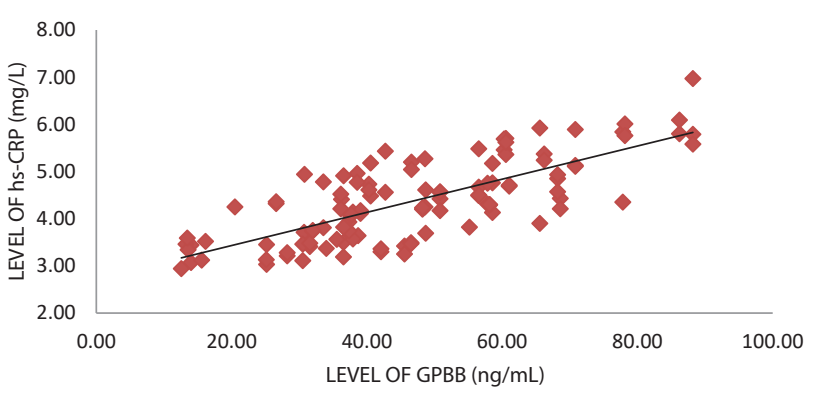

Graph 2: Showing the correlation between hs-CRP and GPBB in AMI Patients.

higher no. of plasma sample with time interval to find out the sensitivity and specificity of the GPBB in AMI patients [18].

The hs-CRP is a chemotactic factor inside fibrinogen, and fibrinogen could make macrophages adhere to the endothelial surface, which would then migrate into the intima, thus promoting plaque rupture and vasoconstriction. Therefore, the elevation of hs-CRP levels in ACS, as instability markers of atherosclerotic lesions, can prompt the coronary plaque instability. There is a large amount of hs-CRP deposition in human early coronary plaque, and the binding of hs-CRP and lipoprotein could activate the complementary system via the classical pathway, resulting in a large number of terminal attack complexes, leading to intimal injury and even plaque rupture $[19,20]$. In our study we found significantly increased level of hs-CRP in AMI group. In 2017 Acharya et al found that serum hs-CRP levels is elevated not only in patients with AMI but also in patients of UA and concluded that hs-CRP estimation may be used for diagnostic and prognostic marker in MI patients [21]. In 2016 Bhasha et al concluded that hs-CRP can play a role in early identification of $\mathrm{MI}$ and can also be used as a confirmatory indicator in post MI patients [22]. Badiger $\mathrm{RH}$ et al showed that the raised hs-CRP level in the majority of patients with AMI suggests involvement of inflammation in the etiopathogenesis of $\mathrm{MI}$ and has prognostic utility in AMI. Higher the serum hs-CRP levels on admission in patients of AMI the more the patient is prone for developing complications during their hospital [23].

When we were correlated the results of hs-CRP and GPBB then we found significant positive correlation between hsCRP and GPBB in the AMI group patients. hs- CRP level is a significant predictor of standard markers for myocardial damage and it may be a useful prognostic marker in acute coronary syndromes [24]. Recently Rathore et al correlated the GPBB and CRP and found the positive correlation between CRP and GPBB in AMI indicates that there occurs inflammation in acute myocardial infarction patients [25].

\section{Conclusion}

Our results demonstrate that there was positive correlation of hs-CRP and GPBB in AMI patients. So along with GPBB, hsCRP is also additional marker of myocardial ischemia and AMI.

Citation: Singh N, Garg C, Rastogi P, Shah R, Rathore V, et al. (2020) Relation of hs-CRP and Glycogen phosphorylase BB in Acute Myocardial Infarction Patients 


\section{References}

1. Kasap S, Gonenc A, Sener DE, Hisar I (2007) Serum Cardiac Markers in Patients with Acute Myocardial Infarction: Oxidative Stress, C-reactive protein and N-terminal probrain natriuretic peptide. J Clin Biochem Nutr 41: 50-57. Link: https://bit.ly/3bbgwHx

2. Thygesen K, Alpert JS, Jaffe AS, Chaitman BR, Bax JJ, et al. (2018) Fourth Universal Definition of Myocardial Infarction. J Am Coll Cardiol 72: 2231-2264. Link: https://bit.ly/2EOm1QA

3. Gupta S, Alagona P (2008) Troponins: not always a myocardial infarction. Am J Med 121: e25. Link: https://bit.ly/3gNuLU5

4. Chen Y, Tao Y, Zhang L, Xu W, Zhou X (2019) Diagnostic and prognostic value of biomarkersin acute myocardial infarction. Postgrad Med J 95: 210-216. Link: https://bit.ly/3bbVUis

5. Wu AH, Feng YJ, Contois JH, Pervaiz S (1996) Comparison of myoglobin, creatine kinase-MB, and cardiac troponin I for diagnosis of acute myocardial infarction. Ann Clin Lab Sci 26: 291-300. Link: https://bit.ly/34Monu4

6. Nigam PK (2007) Biochemical markers of myocardial injury. Indian J Clin Biochem 22:10-17. Link: https://bit.ly/3gJa8Zo

7. Yousuf O, Mohanty BD, Martin SS, Joshi PH, Blaha MJ, et al. (2013) Highsensitivity $\mathrm{C}$-reactive protein and cardiovascular disease: a resolute belief or an elusive link? J Am Coll Cardiol 62: 397-408. Link: https://bit.ly/31IMB6M

8. Hamzic Mehmedbasic A (2016) Inflammatory cytokines as risk factors for mortality after acute cardiac events. Med Arch 70: 252-255. Link: https://bit.ly/2ETtlKs

9. Wang J, Tang B, Liu X, Wang H, Xu D, et al. (2015) Increased monomeric CRP levels in acute myocardial infarction: a possible new and specific biomarker for diagnosis and severity assessment of disease. Atherosclerosis 239: 343349. Link: https://bit.ly/31JdBCM

10. Rabitzsch G, Mair J, Lechleitner P, Noll F, Hofmann U, et al. (1995) Immunoenzymometric assay of human glycogen phosphorylase isoenzyme BB in diagnosis of ischemic myocardial injury. Clin Chem 41: 966-978. Link: https://bit.ly/2YRMYKm

11. Krause EG, Rabitzsch G, Noll F, Mair J, Puschendorf B (1996) Glycogen phosphorylase isoenzyme BB in diagnosis of myocardial ischaemic injury and infarction. Mol Cell Biochem 160: 289-295. Link: https://bit.ly/2EJohbH

12. Mair J (1997) Progress in myocardial damage detection: new biochemical markers for clinicians. Crit Rev Clin Lab Sci 34: 1-66. Link: https://bit.ly/3gM2mxM

13. Singh N, Rathore V, Mahat RK, Rastogi P (2018) Glycogen Phosphorylase BB: A more Sensitive and Specific Marker than Other Cardiac Markers for Early Diagnosis of Acute Myocardial Infarction. Ind J Clin Biochem 33: 356-360. Link: https://bit.ly/31JsGV7

14. Cubranic Z, Madzar Z, Matijevic S, Dvornik S, Fisic E, et al. (2012) Diagnostic accuracy of heart fatty acid binding protein (H-FABP) and glycogen phosphorylase isoenzyme BB (GPBB) in diagnosis of acute myocardial infarction in patients with acute coronary syndrome. Biochem Med (Zagreb) 22: 225-236. Link: https://bit.ly/3lxCvgC

15. Bozkurt S, Kaya EB, Okutucu S, Aytemir K, Coskun F, et al. (2011) The diagnostic and prognostic value of first hour glycogen phosphorylase isoenzyme BB level in acute coronary syndrome. Cardiol J 18: 496-502. Link: https://bit.ly/2YO4dvY

16. Serdar Z, Altin A, Serdar A, Bilgili G, Sarandol E, et al. (2012) Glycogen phosphorylase isoenzyme BB in early diagnosis of acute coronary syndrome. Nobel Medicus 8: 65-72. Link: https://bit.ly/2DdNGKh

17. Lillpopp L, Tzikas S, Ojeda F, Munzel T, Blakenberg S, et al. (2012) Prognostic information of glycogen phosphorylase isoenzyme BB in patients with suspected acute coronary syndrome. Am J Cardiol 110:1225-1230. Link: https://bit.ly/2EP8J6p

18. Peetz D, Post F, Schinzel H, Schweigert R, Schollmayer C, et al. (2005) Glycogen phosphorylase BB in acute coronary syndromes. Clin Chem Lab Med 43:13511358. Link: https://bit.ly/3biUnY8

19. Beaudeux JL, Giral P, Bruckert E, Foglietti MJ, Chapman MJ (2004) Matrix metalloproteinases, inflammation and atherosclerosis: therapeutic perspectives. Clin Chem Lab Med 42: 121-131. Link: https://bit.ly/32yzOCM

20. Wang XH, Liu SQ, Wang YL, Jin Y (2014) Correlation of serum high-sensitivity C-reactive protein and interleukin- 6 in patients with acute coronary syndrome. Genet Mol Res 13: 4260-4266. Link: https://bit.ly/3lvDuOV

21. Acharya A, Sahu JK, Sharma SK, Mandal MK (2017) Serial Measurement of High Sensitive C Reactive Protein Levels of Patients Having Acute Chest Pain -Study in a Tertiary Care Centre of Western Odisha. JMSCR 5: 20243-20246. Link: https://bit.ly/3juwCz7

22. Basha SJ, Anil Kumar M, Lakshmi Prasad KK (2016) Role of HSCRP in Detecting Myocardial Infarction. IOSR-JDMS 15: 19-22.

23. Badiger RH, Dinesha V, Hosalli A, Ashwin SP (2014) hsC-reactive protein as an indicator for prognosis in acute myocardial infarction. J Sci Soc 41: 118-121. Link: https://bit.ly/3IFXLRJ

24. Aseri ZA, Habib SS, Alhomida SA, Khan HA (2014) Relationship of high sensitivity C-reactive protein with cardiac biomarkers in patients presenting with acute coronary syndrome. J Coll Physicians Surg Pak 24: 387-391. Link: https://bit.ly/2EFYGkf

25. Rathore V, Singh N, Rastogi P, Mahat RK (2017) Correlation of inflammatory marker with glycogen phosphorylase BB (GPBB) in patients of acute myocardial infarction. International Journal of Contemporary Medical Research 4: 11221124. Link: https://bit.ly/32UjeOf

\section{Discover a bigger Impact and Visibility of your article publication with} Peertechz Publications

\section{Highlights}

* Signatory publisher of ORCID

* Signatory Publisher of DORA (San Francisco Declaration on Research Assessment)

* Articles archived in worlds' renowned service providers such as Portico, CNKI, AGRIS, TDNet, Base (Bielefeld University Library), CrossRef, Scilit, J-Gate etc.

* Journals indexed in ICMJE, SHERPA/ROMEO, Google Scholar etc.

* OAI-PMH (Open Archives Initiative Protocol for Metadata Harvesting)

* Dedicated Editorial Board for every journal

* Accurate and rapid peer-review process

* Increased citations of published articles through promotions

* Reduced timeline for article publication

Submit your articles and experience a new surge in publication services (https://www.peertechz.com/submission).

Peertechz journals wishes everlasting success in your every endeavours.

Copyright: ( 2020 Singh N, et al. This is an open-access article distributed under the terms of the Creative Commons Attribution License, which permits unrestricted use, distribution, and reproduction in any medium, provided the original author and source are credited. 